\title{
Latest Targeted Therapies in Hormone Receptor Positive, Her2 Neu Negative Breast Carcinoma - A Review Article
}

\author{
Syed Ali Amir Sherazi* \\ Jinnah Hospital, Lahore, Pakistan
}

Received Date: August 21, 2018; Published Date: September 06, 2018

*Corresponding author: Syed Ali Amir Sherazi, Jinnah Hospital, Lahore, Pakistan. Email: syedaliamirsherazi05@gmail.com

\section{Introduction}

Breast cancer is the most frequently diagnosed cancer worldwide, accounting for over a million cases each year. It is also the leading cause of death in women worldwide. According to National Centre for health statistics, 17.3 million new cancer cases and 0.60 million deaths are projected to occur in United States in 2018 due to breast cancer [1]. Breast cancer is treated with a multidisciplinary approach involving surgical oncology, radiation oncology, and medical oncology, which has been associated with a reduction in breast cancer mortality [2].

\section{Patient Stratification}

The treatment approach to breast cancer depends on the stage at presentation. For treatment purposes, breast cancer is characterized using the Tumour, Node, Metastasis system (TNM). Invasive CA Breast can be subdivided into two broad subtypes: invasive ductal carcinoma, and invasive lobular carcinoma [3]. The cancerous cells often show an overexpression of hormone receptors i.e. estrogen receptors + /- progesterone receptors (HR +) or that of an EGF receptor (HER2NEU+) [4]. About 50-70\% of breast cancers are HR+ $(40 \%$ Luminal A, 10-20\% Luminal B) $[3,5]$. This property forms the basis of targeted therapies for breast CA and has opened a whole new spectrum of treatment modalities. This articles focuses on reviewing the latest research work and advancements in therapy for HR+ and Her2 -ve Breast CA.

\section{Goals of Therapy}

Patients with estrogen receptor (ER)-positive metastatic breast cancer often respond to Estrogen therapy alone or in combination with targeted agents, which can reduce tumour burden and symptoms with generally fewer side effects and toxicities than chemotherapy. We make efforts to choose the therapy that is most likely to stabilize or reduce the burden of disease with the fewest side effects and maintain that therapy until either unacceptable toxicities are evident, or disease progression occurs.

\section{Endocrine Therapy}

There are different types of Endocrine Therapies. These can be characterized as approaches to deplete estrogen or to directly target the estrogen receptor (ER).

\section{Depletion of Estrogen}

While therapies to deplete estrogen were accomplished in premenopausal women by oophorectomy, estrogen can now be suppressed with the use of luteinizing hormone-releasing hormone (LHRH) agonists and antagonists. In a randomized trial, the combination of tamoxifen and ovarian suppression with buserelin improved overall survival compared with treatment with either agent alone [6].

\section{Directly Targeting the estrogen receptors}

Selective Estrogen Receptor Modulators (Tamoxifen, Raloxifene) are being used as in premenopausal (as well as postmenopausal) patients with HR+ breast CA $[7,8]$. Tamoxifen has antiestrogenic effects on other tissues. However, Fulvestrant, an estrogen receptor antagonist, has better side-effect profile in this regard and it down-regulates estrogen receptors as well [7,9]. Daily therapy with raloxifene increases bone mineral density, lowers serum concentrations of total and lowdensity lipoprotein cholesterol, and does not stimulate the endometrium [3]. Similarly, Aromatase inhibitors (Anastrozole, Letrozole, Exemestane) can be used in chemo preventive, adjuvant or metastatic setting for hormone receptor positive Breast cancer [10]. Studies show that in post-menopausal cases, aromatase inhibitors should be the preferred first-line adjuvant treatment [11,12]. A meta-analysis evaluating and comparing the effectiveness of all these monotherapies for HR+ HER2NEUBreast cancer patients was performed, including 27 articles with 8 Randomised Control trials and a total of 3492 patients (median age: 63 to 72 years). Letrozole was found to be more efficacious in comparison with tamoxifen and fulvestrant $250 \mathrm{mg}$, with ORR $=0.59$ (95\% CI 0.43-0.80) compared to ORR $=0.54(95 \%$ CI $0.34-0.85$ ) respectively. Considering TPS/PFS, the order of 


\section{Novel Approaches in Drug Designing \& Development}

effectiveness turned out to be: Fulvestrant $500 \mathrm{mg}>$ letrozole $>$ anastrozole $>$ exemestane $>$ tamoxifen $>$ fulvestrant $250 \mathrm{mg}$ [13].

\section{Targeted Therapy with CDK and m TOR Inhibitors}

Although Hormonal therapy has greatly reduced the disease progression in women with HR+ breast cancer, the five-year survival rate for stage IV is $<20 \%$ (2006) [14]. In the past, limited treatment options were available for targeted therapy, but Over the last decade, several prospective randomized clinical trials have demonstrated that addition of agents that mechanistically work in different ways than through ER interference can enhance the benefit seen with ET alone. In particular, cyclin-dependent kinase (CDK) 4/6 inhibitors in combination with ET are often used as a first-line therapy. Three separate agents, palbociclib, ribociclib, and abemaciclib, which inhibit CDK 4/6, improve progression-free survival (PFS) when added to ET as firstline. mTOR inhibitor Afinitor (Everolimus), has also improved progression free survival when added to estrogen therapy in endocrine-resistant setting which received FDA approval in July 2012 based on BOLERO 2 trial. The BOLERO 2, a phase 3 randomised trial, divided 724 patients of advanced (metastatic/ progressed after having received previous treatment) HR+HER2breast cancer patients in two groups (2:1), one group receiving everolimus and exemestane, the other group receiving a placebo with exemestane. The PFS seen in group with everolimus was 86.9 months while the PFS in the placebo group was 2.8 months (C.I $=95 \%$ and $\mathrm{P}<0.001$ ) [15] (Figure 1).

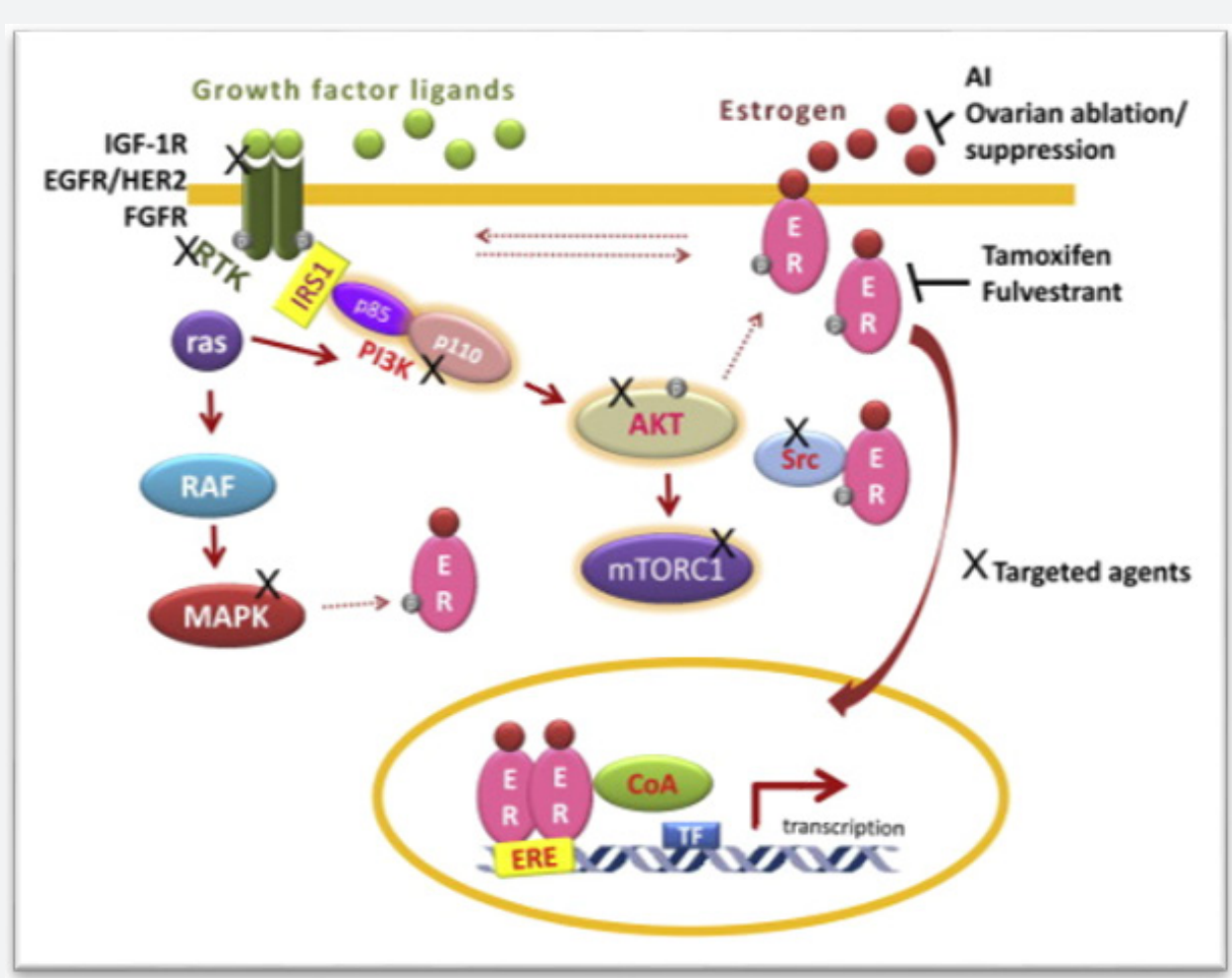

Figure 1: Effect of Therapy on Cellular signaling pathway.

Various studies show that the use of CDK4/6 inhibitors in the treatment of patients with HR+HER2- breast carcinoma as adjuvants, has promising results. Another such study is the MONALEESA-7, randomized phase III double blind trial, in which 672 premenstrual women with HR+ HER2- Breast carcinoma were evaluated in two groups (ratio 1:1). One group received Ribociclib and the other got Placebo with goserelin + tamoxifen or Letrozole or Anastrozole. The trial results show markedly improved progression free interval in subjects who received ribociclib (median PFS 23.8 months) compared to the PFS of the study subjects who received a placebo (13.0 months). The overall response rate being $51 \%$ vs $36 \%(p=3.17 * 10-4)$ [16].

Similarly, a total of 132 patients with advanced metastatic HR+HER2- Breast carcinoma (after having received prior hormonal therapy and 1-2 chemotherapeutic regimens) from
35 areas across four different countries (U.S.A, France, Spain, Belgium) were included in phase 2 MONARCH 1 study, to assess the role of Abemaciclib. Given 200mg Oral drug, Abemaciclib every 12 hours after baseline assessment of the subjects, they were followed every other 28 day cycle and the final assessment after 12 months showed $19.7 \%$ objective response rate $(95 \%$ CI:13.3-27.5), and a progression free survival of 6.0 months [17]. In MONARCH 3 phase 3 trial, 493 postmenopausal patients of HR positive and HER2NEU negative advanced breast carcinoma, without any prior systemic therapy were observed in two groups receiving Abemaciclib with Anastrozole/Letrozole daily, or a Placebo with Anastrozole/Letrozole daily. This study led to the approval of Abemaciclib as a first line agent with aromatase inhibitor, in such patients, by the FDA in February 2018 based on the results having significant prolongation of median 


\section{Novel Approaches in Drug Designing \& Development}

progression free survival in the group receiving abemaciclib (not reached) versus the placebo group i.e. 14.7 months (95\% C.I - 0.41 to $0.72 ; \mathrm{P}=0.000021$, ORR 59\% and $44 \%$ respectively).

In a randomised phase 2 research study, random allocation of 165 post-menopausal HR+HER2- advanced breast carcinoma

Table 1: Statistics on targeted therapy for CDK and mTOR inhibitors. patients was done such that 81 patients received Letrozole alone and 84 patients took Palbociclib+Letrozole. Median PFS of 10.2 months (95\% CI 5.7-12.6) was noted in the letrozole group and that of 20.2 months (13.8-27.5) for the palbociclib plus letrozole group (Tables 1 \& 2) (95\% CI 0.319-0.748, p=0.0004) [18-22].

\begin{tabular}{|c|c|c|c|c|}
\hline FDA approved drugs & Year of approval & Supporting trial & $\begin{array}{l}\text { Median progression } \\
\text { free interval }\end{array}$ & $\begin{array}{c}\text { Overall survival } \\
\text { advantage (p value, } \\
\text { confidence interval) }\end{array}$ \\
\hline Everolimus & $\begin{array}{c}\text { July } 2012 \\
\text { (tentative approval) }\end{array}$ & BOLERO 2 trial & $\begin{array}{l}\text { 7.8months } \\
\text { (vs } 3.2 \text { months) }\end{array}$ & $\begin{array}{c}\mathrm{P}<0.0001 \\
95 \% \text { C.I }\end{array}$ \\
\hline \multirow{2}{*}{ Palbocilcib } & $\begin{array}{c}\text { Feb } 2015 \\
\text { (accelerated approval) }\end{array}$ & $\begin{array}{c}\text { PALOMA-1 trial } \\
\text { (accelerated approval) }\end{array}$ & $\begin{array}{l}20.2 \text { months (vs } 10.2 \\
\text { months for Letrozole } \\
\text { group) }\end{array}$ & $\begin{array}{c}7.5 \text { months vs. } 33.3 \\
\text { months } \\
\text { p }=.280\end{array}$ \\
\hline & $\begin{array}{c}\text { March } 2017 \\
\text { (regular approval) }\end{array}$ & Phase 3 trial PALOMA 2 & $\begin{array}{l}24.8 \text { months (versus } \\
14.5 \text { months for } \\
\text { placebo group) }\end{array}$ & \\
\hline Ribociclib & March 2017 & $\begin{array}{c}\text { Phase } 3 \text { MONALEESA-2 } \\
\text { trial }\end{array}$ & $\begin{array}{l}19.3 \text { months (not } \\
\text { reached) vs } 14.7 \\
\text { months }\end{array}$ & $\begin{array}{c}44 \% \\
\mathrm{p}<0.0001 \\
95 \% \text { C.I }\end{array}$ \\
\hline \multirow{2}{*}{ Abemaciclib } & September 2017 & $\begin{array}{l}\text { MONARCH } 2 \\
\text { clinical trial. }\end{array}$ & $\begin{array}{l}16.4 \text { months (vs } 9.3 \\
\text { months for placebo } \\
\text { group). }\end{array}$ & $\mathrm{p}<.001$ \\
\hline & $\begin{array}{c}\text { February } 2018 \\
\text { (As frontline, with } \\
\text { aromatase inhibitor) }\end{array}$ & MONARCH 3 trial & $\begin{array}{l}28.2 \text { months (vs } 14.8 \\
\text { months for placebo } \\
\text { group) }\end{array}$ & $\begin{array}{c}95 \% \text { CI, } 0.41 \text { to } 0.72 ; \mathrm{P} \\
=.000021\end{array}$ \\
\hline
\end{tabular}

Table 2: Side effects of targeted therapy.

\section{Drugs Toxicities}

\begin{tabular}{|c|c|}
\hline Ribociclib & Neutropenia ( $74.3 \%$ vs $5.2 \%$-any grade) \\
\hline \multirow{8}{*}{ Ribociclib } & Neutropenia ( $74.3 \%$ vs $5.2 \%$-any grade) \\
\hline & Leukopenia $(21.0 \%$ and $0.6 \%$ - grade $3 / 4)$ \\
\hline & Nausea ( $51.5 \%$ vs $28.5 \%$-any grade) \\
\hline & Fatigue ( $36.5 \%$ vs $30.0 \%$-any grade) \\
\hline & Infections ( $50.3 \%$ vs $42.4 \%$-any grade) \\
\hline & Hypertension ( $9.9 \%$ vs $10.9 \%$-grade $3 / 4)$ \\
\hline & Elevated Alanine Aminotranferase (9.3\% vs $1.2 \%$ ) \\
\hline & Diarrhea ( $35.0 \%$ vs $22.1 \%$-any grade) QT prolongation ( $2.7 \%$ vs zero\%) \\
\hline \multirow{7}{*}{ Abemaciclib } & Nausea (45.1\% v $22.9 \%)$ \\
\hline & Diarrhea (86.4\% v 24.7\%) \\
\hline & Neutropenia (46.0\% v 4.0\%) \\
\hline & DVT, Pulmonary embolism (2\% vs $0.4 \%$ ) \\
\hline & Fatigue $(39.9 \%$ v $26.9 \%)$ \\
\hline & Elevated blood LFTs \\
\hline & Teratogenicity \\
\hline
\end{tabular}




\begin{tabular}{|l|c|}
\hline & Neutropenia(79.5\% vs $6.3 \%)$ \\
Palbocilcib & Fatigue( $37.4 \%$ vs $27.5 \%)$ \\
& Nausea( $35.1 \%$ vs $26.1 \%)$ \\
Arthralgia $(33.3 \%$ vs $33.8 \%)$ \\
Alopecia (32.9\% vs $15.8 \%)$ \\
Leukopenia \\
Diarrhea \\
Anemia \\
\end{tabular}

\section{Conclusion}

Patients without rapidly progressive or extensive visceral metastases who are premenopausal, ovarian suppression in combination with Estrogen therapy and a cyclin-dependent kinase (CDK) 4/6 inhibitor are preferred. However, Ovarian suppression with Estrogen therapy without a CDK 4/6 inhibitor is acceptable for those who prefer to avoid the added toxicity of a CDK 4/6 inhibitor. For such patients who are postmenopausal, preference for first-line Estrogen therapy is a CDK 4/6 inhibitor in combination with an aromatase inhibitor. Other options include single-agent fulvestrant or an aromatase inhibitor. The combinations of fulvestrant plus a CDK 4/6 inhibitor or everolimus plus either an Aromatase Inhibitor or tamoxifen are reserved for patients who have progressed on at least one line of ET.

The introduction of Cyclin Dependant Kinase inhibitors has opened a whole new paradigm for the management of HR+ HER2- Breast carcinoma in women.

\section{References}

1. Siegel RL, Miller KD, Jemal A (2018) Cancer statistics, 2018. CA Cancer J Clin 68(1): 7-30.

2. Kesson EM, Allardice GM, George WD, Burns HJG, Morrison DS (2012) Effects of multidisciplinary team working on breast cancer survival: retrospective, comparative, interventional cohort study of 13722 women. BMJ 344: e2718-e2718.

3. Delmas PD, Bjarnason NH, Mitlak BH, Ravoux AC, Shah AS, et al. (1997) Effects of raloxifene on bone mineral density, serum cholesterol concentrations, and uterine endometrium in postmenopausal women. N Engl J Med 337(23): 1641-1647.

4. Makki J (2015) Diversity of Breast Carcinoma: Histological Subtypes and Clinical Relevance. Clinical Medicine Insights Pathology 8: 23-31.

5. Kumar, Vinay, Abul Abbas (2010). Robbins and Cotran Pathologic Basis of Disease. Philadelphia: Saunders, an imprint of Elsevier inc. p. 1090 ISBN 978-1-4160-3121-5.

6. Klijn JG, Beex LV, Mauriac L, van Zijl JA, Veyret C, et al. (2000) Combined treatment with buserelin and tamoxifen in premenopausal metastatic breast cancer: a randomized study. J Natl Cancer Inst 92(11): 903-11.

7. Rick Alteri, Cammie Barnes, Adriane Burke, Ted Gansler, Susan Gapstur Breast Cancer Facts \& Figures 2013-2014, American Cancer Society: Georgia, Europe.
8. Eric P Winer, Clifford Hudis, Harold J Burstein, Antonio C Wolff, Kathleen I Pritchard, et al. (2005) American Society of Clinical Oncology Technology Assessment on the Use of Aromatase Inhibitors As Adjuvant Therapy for Postmenopausal Women With Hormone Receptor-Positive Breast Cancer: Status Report 2004 Journal of Clinical Oncology 23(3): 619-629.

9. Criscitiello C, Fumagalli D, Saini KS, Loi S (2011) Tamoxifen in earlystage estrogen receptor-positive breast cancer: overview of clinical use and molecular biomarkers for patient selection. Onco Targets Ther $4: 1-11$.

10. Chumsri S (2015) Clinical utilities of aromatase inhibitors in breast cancer. International Journal of Women's Health 7: 493-499.

11. Lumachi F, Brunello A, Maruzzo M, Basso U, Basso SM (2013) Treatment of estrogen receptor-positive breast cancer. Curr Med Chem 20(5): 596-604

12. Bonneterre J, Buzdar A, Nabholtz JMA, Robertson JFR, Arimidex Writing Committee on behalf of the Investigators Committee Members, et al. (2001) Anastrozole is superior to tamoxifen as first-line therapy in hormone receptor positive advanced breast carcinoma. Cancer 92: 2247-2258.

13. Zhang J, Huang Y, Wang C, He Y, Zheng S, et al. (2017) Efficacy and safety of endocrine monotherapy as first-line treatment for hormonesensitive advanced breast cancer: A network meta-analysis. Medicine 96(33): e7846.

14. Chen L, Linden HM, Anderson BO, Li CI (2014) Trends in 5-year survival rates among breast cancer patients by hormone receptor status and stage. Breast Cancer Res and Treat 147(3): 609-616.

15. Baselga J, Campone M, Piccart M, Burris HA, Rugo HS, et al. (2012) Everolimus in Postmenopausal Hormone-Receptor-Positive Advanced Breast Cancer. N Engl J Med 366(6): 520-529

16. Tripathy D, Sohn J (2017) Imribociclib vs placebo with goserelin and tamoxifen or a non-steroidal aromatase inhibitor in premenopausal women with hormone receptor-positive, HER2-negative advanced breast cancer: Results from the randomized phase III MONALEESA-7 trial. San Antonio Breast Cancer Conference, abstract GS2-05: USA

17. Dickler MN, Tolaney SM, Rugo HS, Cortés J, Diéras V, et al. (2017) MONARCH 1, A Phase II Study of Abemaciclib, a CDK4 and CDK6 Inhibitor, as a Single Agent, in Patients with Refractory HR+/HER2Metastatic Breast Cancer: Clin Cancer Res 23(17): 5218-5224.

18. Finn R, Crown J, Lang I, Katalin Boer, Igor M Bondarenko, et al. (2015) The cyclin-dependent kinase 4/6 inhibitor palbociclib in combination with letrozole versus letrozole alone as first-line treatment of oestrogen receptor-positive, HER2-negative, advanced breast cancer (PALOMA-1/TRIO-18): a randomised phase 2 study. The Lancet Oncology 16(1): 25-35. 
19. Knudsen ES, Witkiewicz AK (2017) The Strange Case of CDK4/6 Inhibitors: Mechanisms, Resistance, and Combination Strategies. Trends in cancer 3(1): 39-55.

20. Royce ME, Osman D (2015) Everolimus in the Treatment of Metastatic Breast Cancer. Breast Cancer: Basic and Clinical Research 9: 73-79.

21. Mark L. Zangardi, Laura M. Spring, Gayle C. Blouin \& Aditya Bardia (2017): Ribociclib for post-menopausal women with HR+/HER2-

\section{This work is licensed under Creative}

Commons Attribution 4.0 License

DOI: $10.19080 /$ NAPDD.2018.04.555630 advanced or meastatic breast cancer. Expert Review of Clinical Pharmacology 10(11): 1169-1176.

22. Hortobagyi GN, Stemmer SM, Burris HA, Yap YS, Sonke GS et al. (2016) Ribociclib as First-Line Therapy for HR-Positive, Advanced Breast Cancer. N Engl J Med 375(18): 1738-1748.

\section{Your next submission with Juniper Publishers} will reach you the below assets

- Quality Editorial service

- Swift Peer Review

- Reprints availability

- E-prints Service

- Manuscript Podcast for convenient understanding

- Global attainment for your research

- Manuscript accessibility in different formats

( Pdf, E-pub, Full Text, Audio)

- Unceasing customer service

Track the below URL for one-step submission https://juniperpublishers.com/online-submission.php 